\title{
Spatial and temporal analysis of seasonal rainfall on the East Coast of North Sumatra, Indonesia
}

\author{
Nuzul Hijri Darlan ${ }^{1,3}$, Sigit Supadmo Arif ${ }^{2}$, Putu Sudira², and Bayu Dwi Apri Nugroho² \\ ${ }^{1}$ Doctoral student of Department of Agricultural Engineering, Faculty of Agricultural Technology, Universitas \\ Gadjah Mada, Yogyakarta, Indonesia \\ ${ }^{2}$ Department of Agricultural Engineering, Faculty of Agricultural Technology, Universitas Gadjah Mada, Yogyakarta, \\ Indonesia Indonesian Oil Palm Research Institute \\ ${ }^{3}$ Indonesian Oil Palm Research Institute, North Sumatera, Indonesia.
}

Received: 2020-07-26 Accapted: 2020-11-22

\section{Keywords: spatial; \\ seasonal rainfall \\ North Sumatra; \\ El Nino; \\ IOD}

Correspondent email:

nuzulhijri@gmail.com

\begin{abstract}
The east coast of North Sumatra has lower rainfall than the central (Bukit Barisan) and the west coast. Meanwhile, the literature on the influence of climate phenomena, such as El Nino, La Nina, and positive/negative IOD, on the rainfall distribution in North Sumatra remains quite limited. This paper aims to describe the spatial distribution of seasonal rainfall on the east coast of North Sumatra and its correlation with ENSO and the IOD. Hopefully, the spatial analysis of seasonal rainfall and its correlation to ENSO and IOD can improve the understanding on rainfall distribution and the influenced factors in the study area. For 16 years (1999-2014), the monthly rainfall data at 52 rain gauge stations that passed the homogeneity test were divided into the seasonal 6-month and 4-month. Hereafter, the seasonal rainfall was spatially analyzed with the Inverse Distance Weighting (IDW) method using ArcMap software. The spatial analysis results can clearly describe the rainfall dynamics and its anomalies, therefore, can be more easily understood. The repetition of rainfall anomaly patterns can be seen in January to June (JFMAMJ), January to April (JFMA), and May to August (MJJA), which occurs in 3-4 years. Furthermore, the Pearson-correlation analysis shows that SOI has a strong positive correlation on JFMAMJ (0.529), JFMA (0.485), and MJJA (0.366), while IOD has a strong positive correlation on MJJA (0.512) and negative on September to December - SOND (-0.341).
\end{abstract}

O2020 by the authors. Licensee Indonesian Journal of Geography, Indonesia.

This article is an open access article distributed under the terms and conditions of the Creative Common

Attribution(CC BY NC) licensehttps://creativecommons.org/licenses/by-nc/4.0/.

\section{Introduction}

Indonesia is a tropical archipelago country, located on the equator and surrounded by two oceans (Indian and Pacific) and two continents (Asia and Australia). North Sumatra is located in the western part of Indonesia, traversed by the Bukit Barisan mountains, and flanked by Malacca Strait and the Indian Ocean. Thus, Indonesian climate is mostly influenced by the Indian and Pacific Oceans, with at least five factors that affect its rainfall variabilities, such as the local effect (topography), meridional (Hadley) circulation, zonal (Walker) circulation, monsoon activity, and tropical cyclones (Boer and Faqih, 2004). Many studies have found that most occurrences of extreme climate events such as droughts or high-intensity rainfall were associated with the El NiñoSouthern Oscillation, or ENSO, and the Indian Ocean Dipole, or IOD (Fadholi, 2013; Lestari et al., 2018; Mulyana, 2002; Prasetyo, 2018; Sekaranom et al., 2020; Yuggotomo and Ihwan, 2014;).

Generally, Indonesia has three types of rainfall patterns, known as the monsoonal, equatorial, and local types (Aldrian and Susanto, 2003; Lee, 2015; Tukidi, 2010), while North Sumatra experiences equatorial-type rainfall. Nowadays, understanding changes in rainfall pattern and analyzing which factors affect it receives considerable attention from various researchers throughout the world, as any change, usually triggered by extreme weather events such as droughts or floods, could threaten agricultural productivity and increase ecological damage or fire risk (He et al., 2018; Suhaila and Jemain, 2012). Improved knowledge of these patterns will help the government or decision-makers to prevent more significant loss or damage to agriculture productivity.

Many studies across the globe have used spatial analysis to identify and understand rainfall patterns in locations such as Morocco (Salhi et al., 2019), Australia (Yang et al., 2015; Saunders et al., 2017), Ethiopia (Alemu and Bawoke, 2019), Iran (Zeinivand, 2015), Taiwan (Lee et al., 2020), Malaysia (Suhaila and Jemain, 2012), India (Ghosh, 2018), and Indonesia (Lee, 2015; Nugroho, 2015). Ly et al. (2011) found that Inverse Distance Weighting (IDW) is the best method for spatial interpolation since it provides the smallest RMSE (Root Mean Squared Error) compared to KED (Kriging with an External Drift), OCK (Ordinary Cokriging), and UNK (Universal Kriging). Similar results were found by Yang et al. (2015), suggesting that IDW is preferable to three other methods (ANUDEM, Spline, Kriging) and easy to implement in a geographic information system (GIS). Chen and Liu 
(2012) found that the radius influence of the IDW method was over $30 \mathrm{~km}$ and that the method was more accurate during the dry season.

Unfortunately, published studies of the rainfall trends in Indonesia have mostly been conducted on the island of Java and are very limited on other islands including Sumatra, especially North Sumatra. The rainfall in Java is greatly influenced by ENSO and has a clear dry season, while North Sumatra rarely experiences rainfall of less than $60 \mathrm{~mm} /$ month. The correlation and influence of ENSO and the IOD on the rainfall variability in North Sumatra was also unclear; whereas several studies have stated that it is not influenced by ENSO and IOD (Aldrian, 2002; Lestari et al., 2018; Mulyana, 2002; Nasution and Nuh, 2018; Qian, 2019), other studies have stated the contrary, especially in the eastern coastal region (Irwandi et al., 2017). Moreover, the occurrence of rainfall below $60 \mathrm{~mm} /$ month in January to March 2014 on the eastern coast of North Sumatra, which rarely occurred, led to a $25 \%$ loss in oil palm productivity in the following year (Pradiko et al., 2016), emphasizing the importance of this study to understand rainfall patterns in order to prevent greater productivity losses. This article will describe and discuss the spatial distribution of seasonal rainfall on the east coast of North Sumatra and its correlation with ENSO and the IOD.

\section{The Methods}

The East Coast of North Sumatra is located at $1045^{\prime}-4^{03} 0^{\prime}$ $\mathrm{N}$ and $97050^{\prime}-100^{\circ} 20^{\prime} \mathrm{E}$. It contains thirteen districts: Serdang Bedagai, Medan, Langkat, Tebing Tinggi, Deli Serdang, Batubara, Asahan, Pematang Siantar, Simalungun, Tanjung Balai, Labuhan Batu, North Labuhan Batu and South Labuhan Batu. The boundaries of the study area are Aceh Province and Malacca Strait in the north, Riau Province in the south, the Bukit Barisan mountains in the west and the Malacca Strait in the east.

Over 16 years (1999-2014) of monthly rainfall data series were taken from seventy-four rain gauge locations owned by BMKG (North Sumatra Agency for Meteorology, Climatology, and Geophysics) and the government or private oil palm plantations in the study area. The 16 years of monthly historical data were considered sufficient for analysis of rainfall patterns, following the approach of Kisaka et al. (2014), which used 13 years of data to analyze rainfall variability in Kenya. Supporting Kisaka, Brisson et al. (2015) stated that at least 10 years of historical rainfall data were needed to describe rainfall patterns and at least 30 years to analyze climate change in any region. Furthermore, the data were tested for homogeneity using the Pettit method (Kang and Yusof, 2012) and resulted in 52 locations that are homogenous (Figure 1).

The collected data were first analyzed to understand their annual distribution by plotting as a chart (Figure 2). Based on the chart, the monthly data are divided into seasons of 6 months and 4 months. The 6-month classifications used in this study are January to June (JFMAMJ) and July to December (JASOND), which are commonly used by the local society to describe the dry season and wet season, related to the equatorial-type rainfall in North Sumatra with two rainfall peaks (Hermawan, 2010; Prasetyo, 2018). The 4month classifications used in this study are from January to April (JFMA), May to August (MJJA), and September to December (SOND). Farmers commonly use these seasons to define the dry, transitional, and wet seasons (Boer and Faqih, 2004). The average rainfall distribution showed that JFMA has the lowest rainfall $(142 \mathrm{~mm} / \mathrm{month})$ and SOND has the highest rainfall ( $250 \mathrm{~mm} / \mathrm{month})$, while MJJA is intermediate between these with as much as $167 \mathrm{~mm} /$ month.

The SOI index and IOD index were then classified into 6month and 4-month seasons, similar to the rainfall data. Based on the Chiew method classification (Chiew et al., 1998), the El Niño years during the observation period were 2003, 2007 and 2010, and the La Niña years were 1999, 2008, and 2011. The average SOI index over twelve months (April to March) was used to define ENSO events. If the SOI value is below -5 then the year is classified as an El Niño, while values above +5 are classified as La Niña events. If two consecutive years are classified as El Niño or La Niña, then only the first year is considered to be an El Niño or La Niña, and the second is classed as Neutral. The classification of IOD events as negative (IOD index $<-0.4$ ) and positive (IOD index >0.4) was based on the classification described by the Australian Bureau of Meteorology.

The data were then analyzed spatially using ArcMap 10 software with the Spatial Analyst tool. The IDW method used in this study is a commonly-applied and deterministic interpolation method used for rainfall data; it has small errors, is easier to use, and is computationally faster compared to other interpolation methods (Chen and Liu, 2012; Ly et al., 2011; Yang et al., 2015). The IDW method estimates an unknown value by calculating the weighted average of observed data at surrounding points. The values at unknown points are determined by the search distance, the nearest point, a power parameter, and obstacle settings from nearby known observation points. The known sample points are assumed to be independent of each other (Bhunia et al., 2016; Zeinivand, 2015). The formula used is: $\left.z \_p=\left(S \_(i=1)^{\wedge} n\left(z \_i /\left(d \_i \wedge(p)\right)\right)\right) /\left(S \_(i=1) \wedge n\left(1 / d \_i \wedge(p)\right)\right)\right)(1)$

where $z_{\mathrm{p}}$ is the interpolated value, $\mathrm{n}$ represents the total number of sample data values, $z_{i}$ is the $i$-th data value, $d_{i}$ is the separation distance between the interpolated value and the sample data value, and $\mathrm{p}$ denotes the weighting power.

\section{Results and Discussion}

Generally, the rainfall on the east coast of North Sumatra is smaller than on the west coast. This is due to the movement of wet air masses carried from the Indian Ocean were obstructed by the Bukit Barisan mountains, causing the East Coast region to receive only wet air masses from Malacca Strait and those brought by the monsoon during the rainy season (Hermawan, 2010). During the observational period, the study area's annual precipitation ranged between 1,885 and 2,577 $\mathrm{mm} /$ year. The rainfall peaks occurred in May (190 $\mathrm{mm} / \mathrm{month})$ and October $(289 \mathrm{~mm} / \mathrm{month})$, related to the equinox phenomenon that causes warming of the sea surface temperature around the equator and then triggers clouds and rain (Sinambela et al., 2008).

The overview analysis in this study showed that anomalies in average 5-year annual precipitation in the study area were above normal (positive) in 2003, 2006-2009 and 2011-2013, and below average (negative) in 2002, 2004-2005, 2010, and 2014-2015 (Figure 3), similar to results found in Prasetyo (2018). That study showed that the anomalies in average 5year annual precipitation on the East Coast of North Sumatra (taken from four rain-posts) were significantly different for 


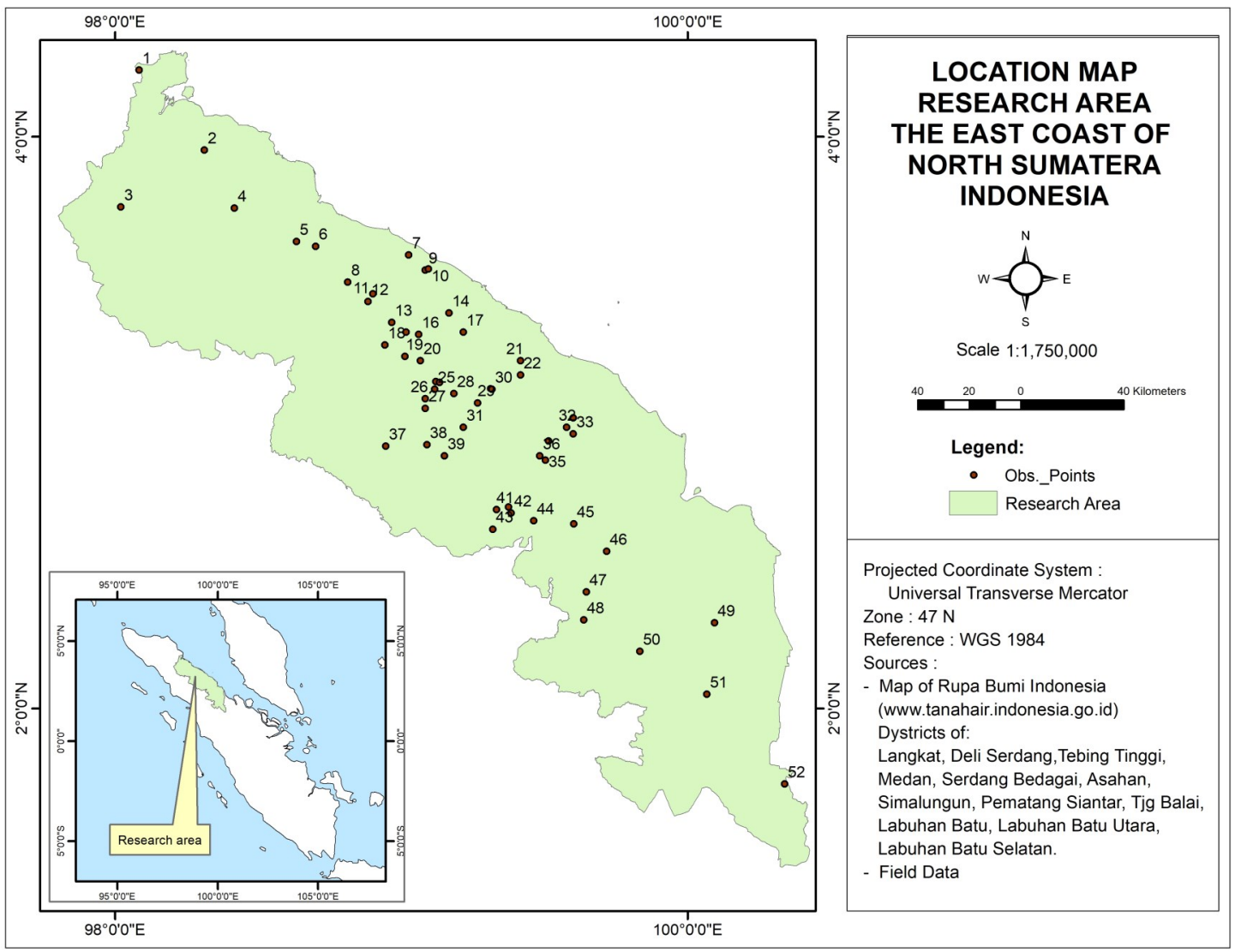

Figure 1. The rainfall stations distribution in the study area

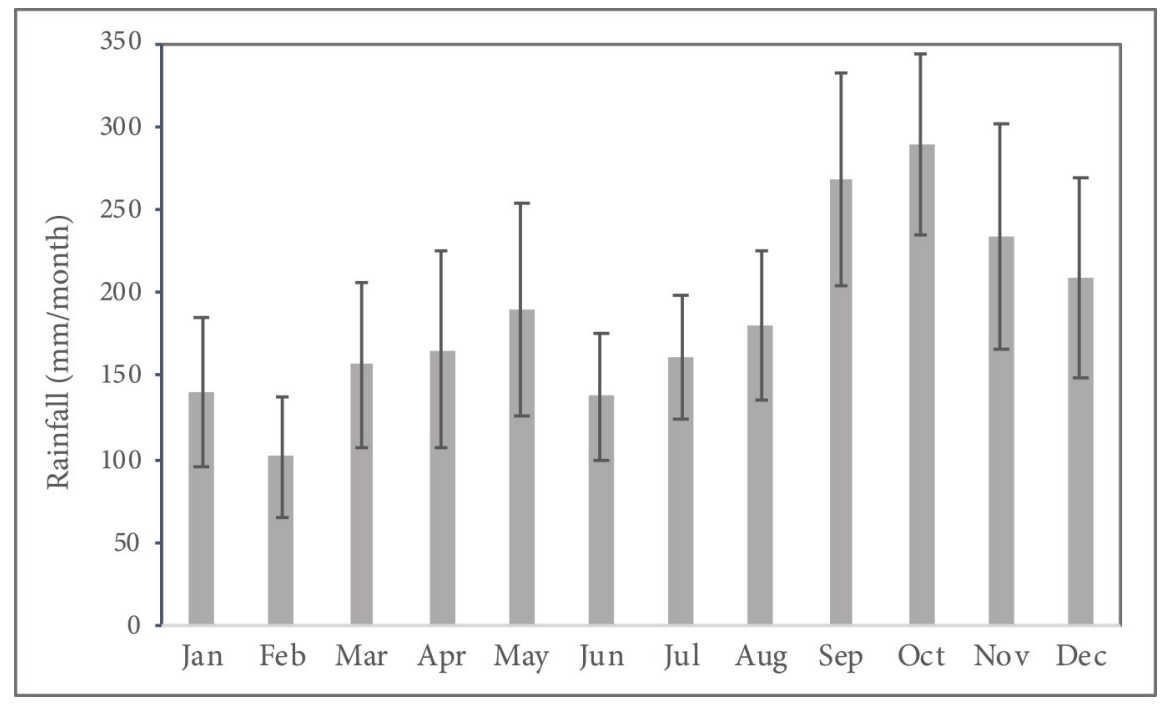

Figure 2. Average monthly rainfall distribution at the study area during 1999-2014

the decade before and the decade after 1998, with belownormal anomalies before 1998 and more variability after, allegedly due to ENSO fluctuations since IOD tended to be normal in 2000-2010.

\section{6-Month Seasonal Rainfall}

The spatial analysis of JFMAMJ and JASOND data showed that the rainfall distributions over both periods contrast with each other (Figure 4). The eastern area adjacent to the Malacca Strait is drier than the western area adjacent to the Bukit Barisan mountains. Each year's rainfall dynamics tend to be different, and no identical pattern was found during the observational period.
The JFMAMJ data represent the first rainfall peak and the dry season in the study area. The results show that the study area was dominated by rainfall of $125-200 \mathrm{~mm} /$ month (orange, yellow, and green) during the study period. Several years were dominated by rainfall of $<125 \mathrm{~mm} /$ month (red) in over $50 \%$ of the study area, occurring in 2002, 2004, 2005, 2008 , and 2014. Even so, in certain years, some areas are also visible in rainfall of $>250 \mathrm{~mm} /$ month (blue), such as in 1999, 2000, 2003, 2006, 2009, and 2011-2013.

The JASOND data represent the second rainfall peak and the wet season in the study area. The results show that the study area was dominated by rainfall of $200-275 \mathrm{~mm} /$ month (green and light blue) during the study time. Several years 


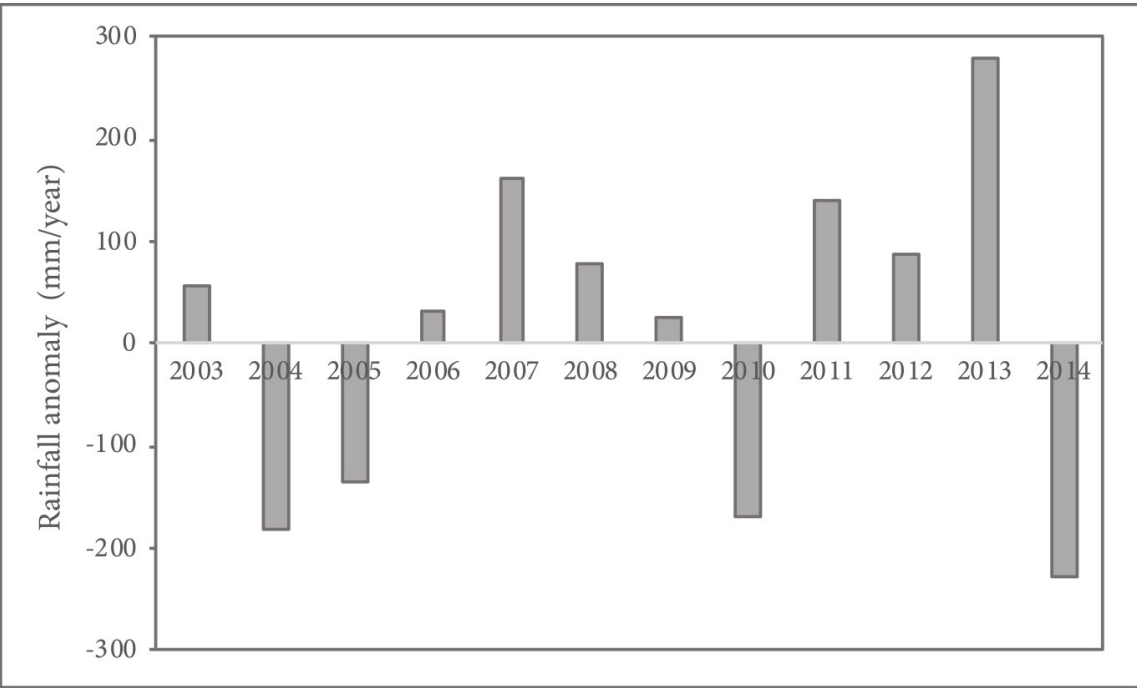

Figure 3. The anomaly of average 5-year annual precipitation in the study area

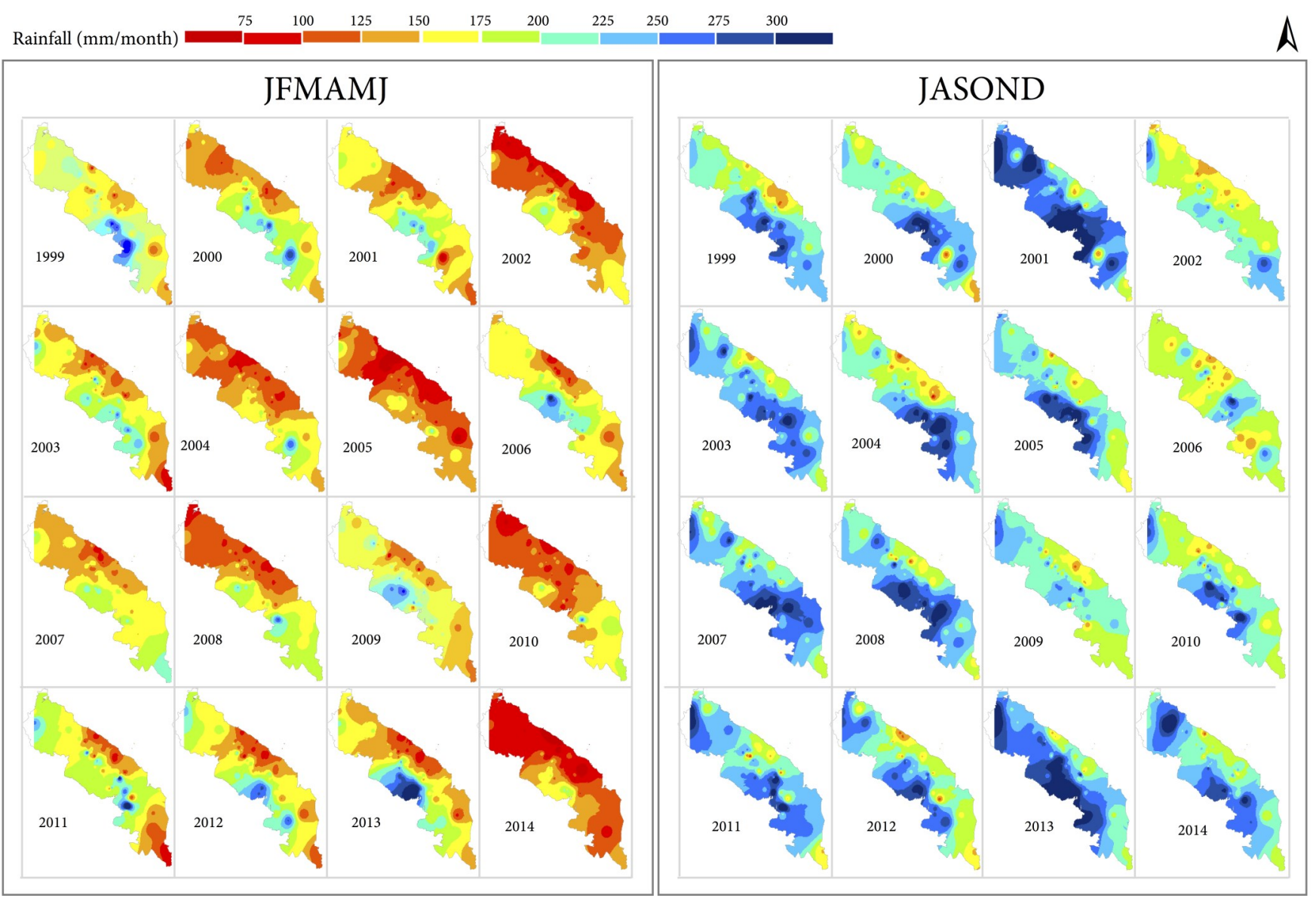

Figure 4. Seasonal (JFMAMJ and JASOND) rainfall distribution after interpolation with IDW

were dominated by rainfall of $>250 \mathrm{~mm} /$ month (dark blue) in over $50 \%$ of the study area, occurring in 2001, 2003, and 2013. Even so, there are several spots where rainfall was $125-$ $150 \mathrm{~mm} / \mathrm{month}$ (orange), which occur almost every year during the observation period.

The rainfall amount in the JFMAMJ period was always lower than in the JASOND period by approximately $75 \mathrm{~mm}$. The analysis of average 5-year seasonal precipitation (JFMAMJ) anomalies in the study area showed that the anomaly was positive in 2006, 2009, and 2011-2013; negative in 2004, 2005, 2010, and 2014; and normal in 2003, 2007, and
2008. Thereafter, the anomaly during JASOND was positive in 2007, 2008, and 2013; then negative in 2004, 2006 and 2009; and normal in 2003, 2005, 2010-2012 and 2014 (Figure $5)$. It can also be seen that rainfall anomaly patterns in JFMAMJ repeated over a span of 3-4 years.

Furthermore, almost every positive and negative anomaly in both periods can be described clearly in the spatial analysis results. As can be seen in Figure 4, when the positive anomaly occurred in the JFMAMJ period, the blue spots (rainfall $>225 \mathrm{~mm} / \mathrm{month}$ ) appeared in several areas, and when negative anomalies occurred, red (rainfall $<125 \mathrm{~mm} /$ 
month) was dominant. In contrast, in the JASOND period, the positive anomaly appeared through the dominance of dark-blue (rainfall $>275 \mathrm{~mm} / \mathrm{month}$ ), and the negative anomaly appeared as green and yellow (rainfall of 150-175 $\mathrm{mm} / \mathrm{month}$ ) spots in several areas. This is similar to Australia's study that stated the ENSO could affect the distribution of spatial extremes rainfall, where the La Nina phase has a more significant impact on the extreme rainfall distribution than the El Nino phase (Saunders et al., 2017).

The positive rainfall anomalies in JFMAMJ and JASOND were not always coherent with La Niña events, as in 2009 (a La Niña year), the anomaly in JASOND was negative. Furthermore, several positive anomalies in both periods were not coherent with La Niña events. Similar to the positive anomalies, negative anomalies also did not consistently correspond to El Niño events. In 2007 (an El Niño year), instead of a negative anomaly occurring, the anomaly was significantly positive in JASOND. The El Niño and negative IOD in 2010 caused a significant negative anomaly in JFMAMJ, but in JASOND the anomaly was normal.

IOD events also showed coherence with the JFMAMJ rainfall anomaly in other years, namely in 2012 and 2014, when the IOD and the anomaly were positive and negative. However, the coherence between the IOD and rainfall anomalies in JFMAMJ and JASOND seems to have the opposite influence: for every positive or negative rainfall anomaly in JFMAMJ, the positive or negative IOD tended to reduce and neutralize the anomaly. This is similar to Boer and Faqih (2004) statement that a negative IOD could reduce the El Niño impact on rainfall decrease in Bandung.

Hence, a simple Pearson correlation coefficient analysis was conducted on seasonal rainfall with the SOI and IOD to determine the correlations (Ruigar and Gulian, 2015). The results showed that the rainfall in the JFMAMJ period has a strong positive correlation to SOI (0.529) and is very weakly correlated to IOD (0.153), while the rainfall in JASOND period has a weak correlation to both SOI (0.293) and IOD (0.290). In line with this finding, Irwandi et al. (2017) also stated that El Niño events had decreased the rainfall on the east coast of North Sumatra by as much as $8 \%(51-100 \mathrm{~mm})$.

While other studies (Aldrian, 2002; Lestari et al., 2018; Mulyana, 2002; Qian, 2019) have stated that ENSO does not influence rainfall variability in North Sumatra, this could be due to these studies being conducted over a greater area
(Indonesia region), while examining the ENSO influence in Sumatra, Singapore, and Malaysia. Furthermore, all of these studies used satellite-estimated precipitation data, such as the Global Precipitation Climatology Centre (GPCC), Global Historical Climate Network (GHCN), and National Ocean and Atmospheric Administration (NOAA), while Irwandi et al. (2017) used data collected from rain gauges located in North Sumatra. Thus, that study was more specific and represented local rainfall variability.

\section{4-Month Seasonal Rainfall}

The spatial analysis for JFMA, MJJA, and SOND showed more clearly the seasonal rainfall distribution in North Sumatra (Figure 6). The first period (JFMA) represents the dry season, which was dominated by rainfall of $<175 \mathrm{~mm} /$ month (yellow to red) but the red, indicating low rainfall, dominated more frequently than in JFMAMJ. The years with the most dominant red color occurred in 2005, 2010, and 2014, where 2010 was an El Niño year, and a negative IOD occurred in 2014, but there were no ENSO or IOD events in 2005.

The second period (MJJA) is the transition from the dry to the rainy season, which was slightly wetter than the first period ( $22 \mathrm{~mm}$ difference) and dominated by rainfall of 125 $200 \mathrm{~mm} / \mathrm{month}$ (orange to light blue). However, unlike in any other years in this period, the year 2002 was dominated by rainfall of $<150 \mathrm{~mm} /$ month (red and orange), even dryer than in the previous period, although there were no ENSO or IOD events in that year.

The third period (SOND) is the wettest and is also known as farmers' rainy season. It was dominated by rainfall of $>200 \mathrm{~mm} / \mathrm{month}$ (light blue to dark blue). Like other periods, this period also has years with dominantly high (>275 mm/month), in dark blue, which occurred in 2001, 2013, and 2014. Of those three years, only 2014 coincided with a negative IOD, while other years did not coincide with ENSO or IOD events.

Similar to the spatial analysis results for JFMAMJ and JASOND, almost all of the rainfall anomalies that occurred in JFMA, MJJA, and SOND were well described by the spatial analysis. As can be seen in Figure 6, the negative rainfall anomalies in JFMA, MJJA, and SOND were indicated by the dominance of red, orange, and yellow spots, respectively. Meanwhile, the positive anomalies were indicated by the
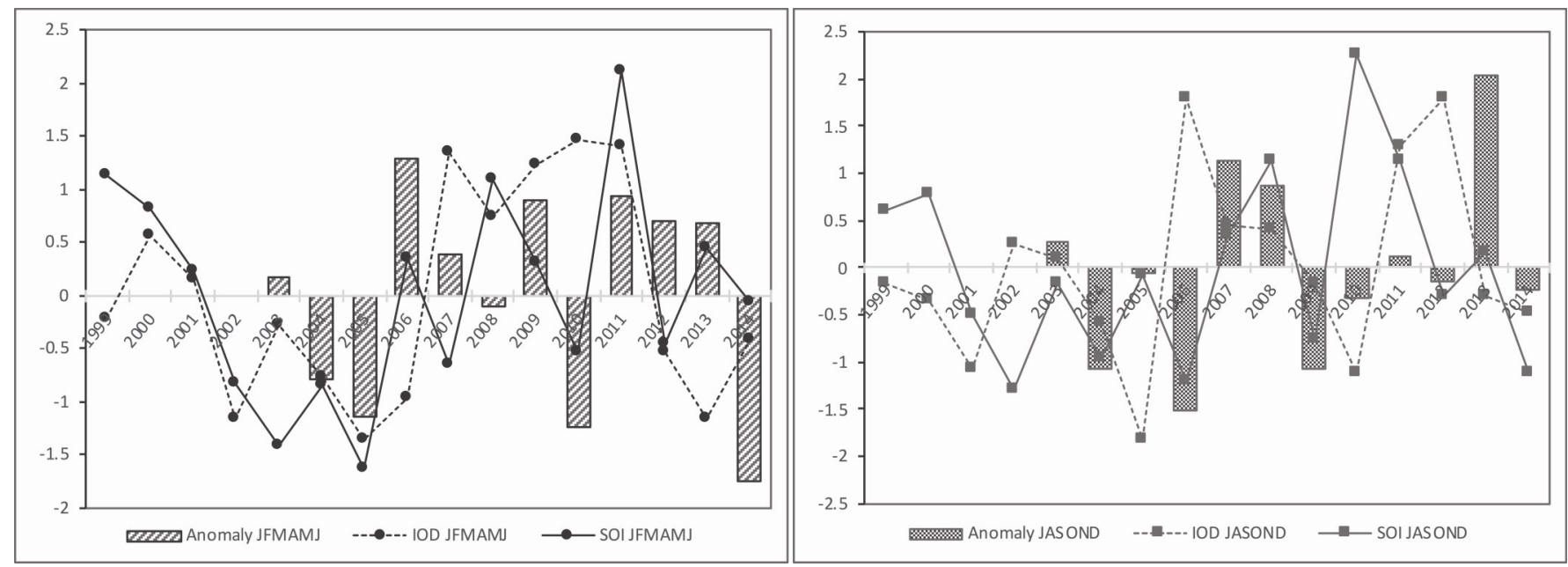

Figure 5. The standardize of seasonal rainfall, SOI, and IOD on JFMAMJ (left) and JASOND (right) distribution 
presence of blue spots, light blue spots, and dominantly blue coloration, respectively.

The analysis of anomalies in average 5-year seasonal precipitation during the first period (JFMA) showed that the anomalies were positive in 2008, 2009, and 2011-2013; negative in 2004, 2005,2010, and 2014; and normal in 2003, 2006 , and 2007. The MJJA period showed a positive anomaly in 2005-2007 and 2012; negative in 2009, 2013, and 2014; and normal in 2003, 2004, 2008, 2010, and 2011. The SOND period had positive anomalies in 2007 and 2013; negative in 2004, 2006, 2009, and 2010; and normal in 2003, 2005, 2008, 2011, 2012, and 2014 (Figure 7). The repetition of rainfall anomaly patterns can also be seen in JFMA and MJJA, which also occurred for 3-4 years.

Every positive anomaly in JFMA, except in 2013, is coherent with a La Niña event. In MJJA, two anomalies (2006 and 2012) were coherent with positive IOD events, while in SOND, the anomaly (2013) was incoherent with ENSO or IOD events. Furthermore, the negative anomalies in JFMA in 2004-2005, 2010, and 2014 were respectively incoherent with IOD and ENSO events, coherent with an El Niño event, and coherent with a negative IOD event. Apparently, the negative IOD events in 2010 and 2014 resulted in negative anomalies in most JFMA, MJJA and SOND periods.
Therefore, a simple Pearson correlation coefficient analysis was also conducted to determine the relationship of these three seasonal rainfalls with the SOI and IOD. The result showed that the rainfall patterns in JFMA and MJJA had strong positive correlations to SOI, with values of 0.485 and 0.366 , respectively, while SOND rainfall did not correlate with SOI (0.043). Furthermore, the JFMA did not correlate with the IOD (0.135), while a strong positive correlation was found in MJJA (0.512), and a moderate negative correlation was found in SOND (-0.341). This is similar to Lee's (2015) findings, which stated that the Dipole Mode Index has a positive correlation with the rainfall in Northern Sumatra and Western Kalimantan and a negative correlation in the central area of Indonesia. While in Taiwan, the rainfall has negative correlations with ENSO indices in March and positive correlations in October (Lee et al., 2020).

\section{Conclusion}

The spatial analysis can clearly describe the dynamics of rainfall distribution in the study area, showing that the eastern area adjacent to Malacca Strait has the least rainfall, with rainfall increasing westward. The analysis can also represent the change in rainfall patterns due to rainfall

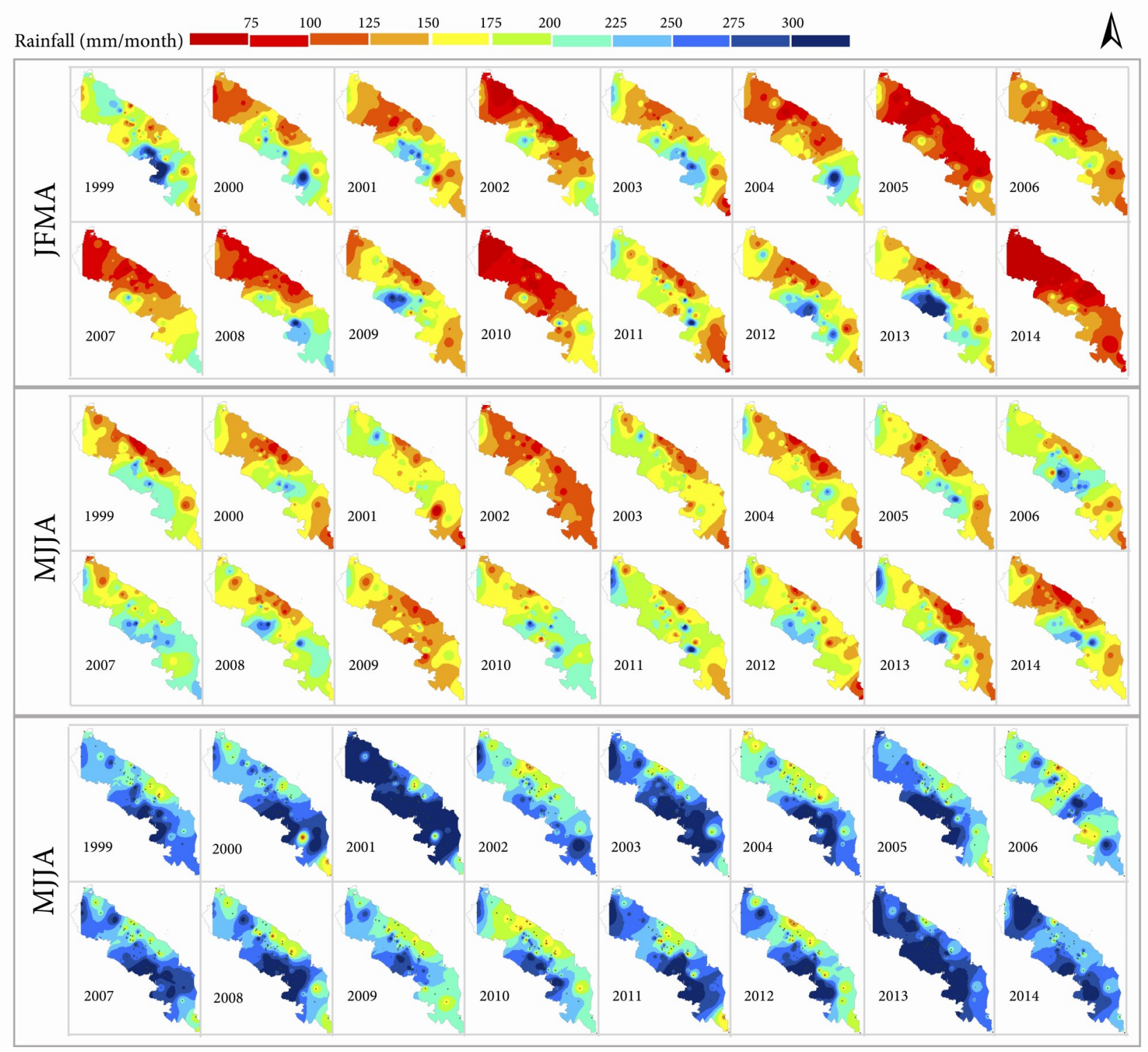

Figure 6. The 4-month (JFMA, MJJA, SOND) rainfall distribution after interpolation with IDW 

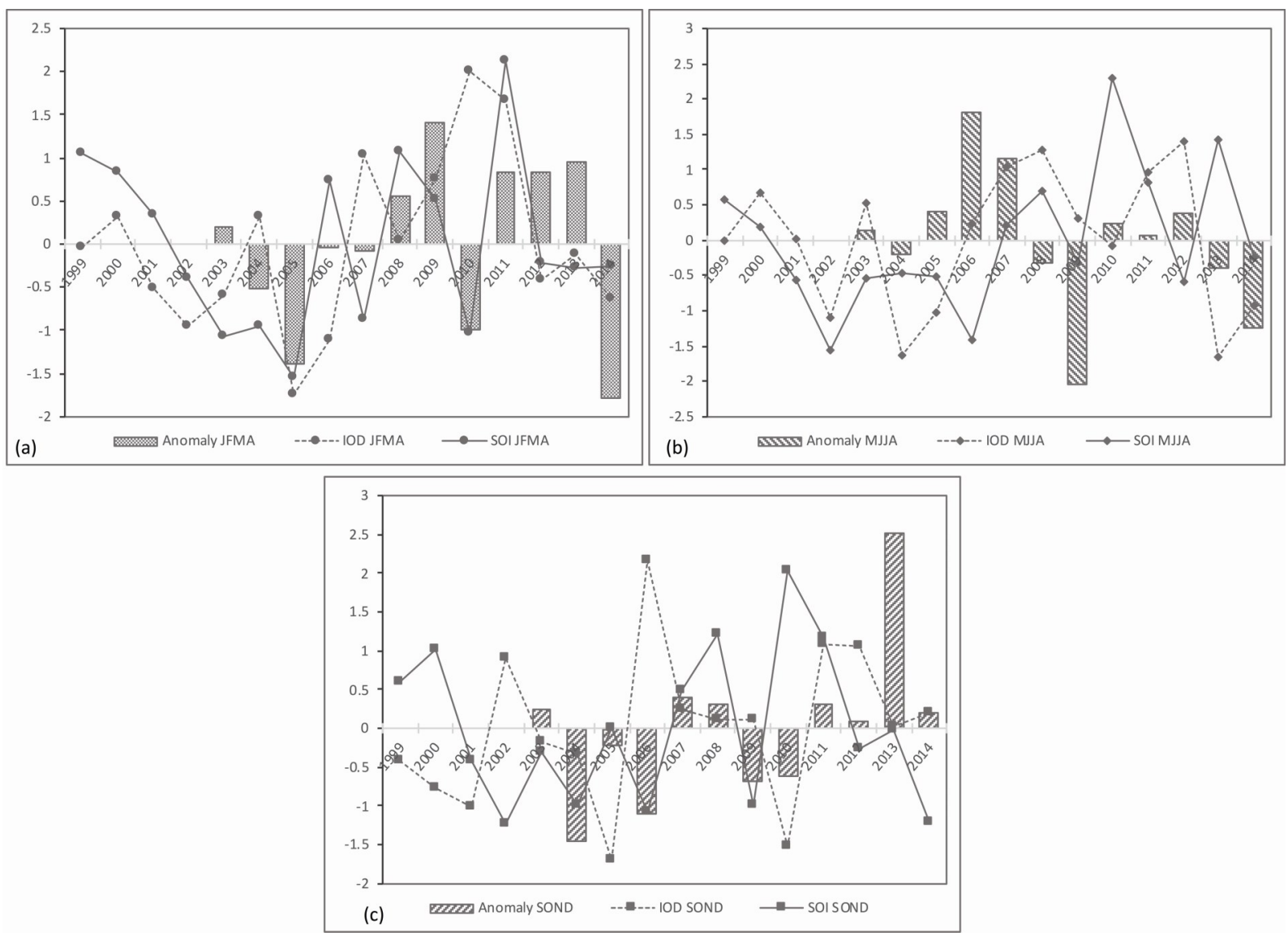

Figure 7. The standardize of seasonal rainfall, SOI, and IOD on JFMA (a), MJJA (b), and SOND (c) distribution

anomalies. The repetition of rainfall anomaly patterns can be seen in seasonal periods with less rainfall, namely JFMAMJ, JFMA, and MJJA, occurring over 3-4 years.

The 4-month seasonal rainfall data delivered the best correlation to the SOI and IOD, showing that the SOI had a strong positive correlation to seasonal rainfall in JFMA and MJJA, while the IOD had a strong positive correlation in MJJA and a moderate negative correlation in SOND.

However, several anomalous occurrences cannot be explained by the variability of ENSO and the IOD. These may be associated with other climatic phenomena that need further study.

\section{Acknowledgment}

The authors thank Darmayanti and Dhimas Wiratmoko for their support in data collection and comprehend ArcMap's analysis.

\section{References}

Aldrian, E. (2002). Spatial Patterns of ENSO Impact on Indonesian Rainfall. Jurnal Sains \& Teknologi Modifikasi Cuaca. 3(1). 5-15. https://doi.org/10.29122/jstmc.v3i1.2154.

Aldrian, E. and Susanto, D. (2003). Identification of Three Dominant Rainfall Regions Within Indonesia and Their Relationship to Sea Surface Temperature. Int. J. Climatol. 23. 14351452. http://doi.org/10.1002/joc.950.

Alemu, M. M. and Baweke, G. T. (2019). Analysis of Spatial Variability and Temporal Trends of Rainfall in Amhara Region, Ethiopia. Journal of Water and Climate Change. In press. http://doi.org/10.2166/wcc.2019.084.

Bhunia, G.S., Shit, P. K., and Maiti, R. (2016). Comparison of GISbased interpolation methods for spatial distribution of soil organic carbon (SOC). Journal of the Saudi Society of Agricultural Sciences. 17(2). 114-126. https:// doi.org/10.1016/j.jssas.2016.02.001.

Boer, R. and Faqih, M. (2004). Global Climate Forcing Factors and Rainfall Variability in West Java: Case Study in Bandung District. J. Agromet 18(2). 1-12. https://doi.org/10.29244/ j.agromet.18.2.1-12.

Brisson, E., Demuzere, M., Willems, P., van Lipzig, N. P. M. (2015). Assesment of Natural Climate Variability Using a Weather Generator. Clim Dyn. 44. 495-508. https:// doi.org/10.1007/s00382-014-2122-8.

Chen, F-W. and Liu, C-W. (2012). Estimation of the spatial rainfall distribution using inverse distance weighting (IDW) in the middle of Taiwan. Paddy and Water Environment. 10 (3). 209-222. https://doi.org/10.1007/s10333-012-0319-1.

Chiew, F. H. A., Piechota, T. C., Dracup, J. A., and McMahon, T. A. (1998). El Nino Southern Oscillation and Australian Rainfall, Streamflow, and Drought: Links and Potential for Forecasting. Journal of Hydrology. 204(1). 138-149. https://doi.org/10.1016/S0022-1694(97)00121-2.

Fadholi, A. (2013). Studi Dampak El Nino dan Indian Ocean Diole (IOD) Terhadap Curah Hujan di Pangkalpinang. Jurnal Ilmu Lingkungan. 11(1). 43-50. https://doi.org/10.14710/ jil.11.1.43-50.

Ghosh, K. G. (2018). Analysis of Rainfall Trends and its Spatial Patterns During the Last Century over the Gangetic West Bengal, Eastern India. Journal of Geovisualization and Spatial Analysis. 2(15). http://doi.org/10/1007/s41651-018 -0022-x.

He, X., Koch, J., Zheng, C., Bovith, T., and Jensen, K. H. (2018). Comparison of Simulated Spatial Patterns Using Rain Gauge and Polametric-Radar-Based Precipitation Data in Catchment Hydrological Modeling. Journal of Hydrometeorology. 19(August). 1273-1288. http:// doi.org/10.1175/JHM-D-17-0235.1. 
Hermawan, E. (2010). Pengelompokan Pola Curah Hujan yang Terjadi di Beberapa Kawasan P.Sumatra Berbasis Hasil Analisis Teknik Spetral. Jurnal Meteorologi dan Geofisika. 11(2). 75-85. http://doi.org/10.31172/jmg.v11i2.67.

Irwandi, H., Nasution, M. I., Kurniawan, E., and Megalina, Y. (2017). Pengaruh El Nino Terhadap Variabilitas Curah Hujan di Sumatra Utara. Fisitek: Jurnal Ilmu Fisika dan Teknologi. 1(2). 7-15. http://dx.doi.org/10.30821/ fisitek.v1i2.1319.

Kang, H. M. and Yusof, F. (2012). Homogeneity Tests on Daily Rainfall Series in Peninsular Malaysia. Int. J. Contemp. Math. Sciences. 7(1).9-22. http://doi.org/10.9790/09900503025763.

Kisaka, M.O., Mucheru-Muna, M., Ngetich, F. K., Mugwe, J. N., Mugendi, D., and Mairura, F. (2014). Rainfall Variability, Drought Characterization, and Efficacy of Rainfall Data Reconstruction: Case of Eastern Kenya. Advances in Meteorology. 2015. 16 pages. https:// doi.org/10.1155/2015/380404.

Lee, H. S. (2015). General Rainfall Patterns in Indoneisa and the Potential Impacts of Local Seas on Rainfall Intensity. Water. 7. 1751-1768. https://doi.org/10.3390/w7041751.

Lee, J. H., Yang, C-Y., Julien, P. Y. (2020). Taiwanese rainfall variability associated with large-scale climate phenomena. Journal Advances in Water Resources. 135. http:// doi.org/10.1016/j.advwaters.2019.103462.

Lestari, D. O., E. Sutriyono, Sabaruddin, and Iskandar, I. (2018). Respective Influences of Indian Ocean Dipole and El Nino Southern Oscillation on Indonesian Precipitation. J. Math. Fund. Sci. 50(3). 257-272. https://doi.org/10.5614/ j.math.fund.sci.2018.50.3.3.

Ly, S., Charles, C., and Degré, A. (2011). Geostatistical interpolation of daily rainfall at catchment scale: the use of several variogram models in the Ourthe and Ambleve catchments, Belgium. Hydrology and Earth System Sciences. 15(7). 2259-2274. https://doi.org/10.5194/ hess15-2259-2011.

Mulyana, E (2002). Hubungan antara ENSO dengan variasi curah hujan di Indonesia. Jurnal Sains \& Teknologi Modifikasi Cuaca. 3(1). 1-4.

Nasution, M. I. and Nuh, M. (2018). Kajian Iklim Berdasarkan Klasifikasi Oldeman di Kabupaten Langkat. JISTech. 3(2). 1-19. http://dx/doi.org/10.30829/jistech.v3i2.3157.

Nugroho, B. D. A. (2015). Relationship between Sea Surface Temperature (SST) and Rainfall Distribution Pattern in South-Central Java, Indonesia. Indonesian Journal of Geography. 47(1). 20-25. https://doi.org/10.22146/ijg.6742.

Pradiko, I., Darlan, N. H., dan Siregar, H. H. (2016). Kajian Anomali Iklim terhadap Penurunan Produksi Kelapa Sawit di Sumatra Utara. Warta PPKS, 21(1). 7-18. ISSN 0853-2141.

Prasetyo, B., Irwandi, H., and Pusparini, N. (2018). Variable Topography-Based Rainfall Characteristic in North Sumatra. Jurnal Sains \& Teknolgi Modifikasi Cuaca. 19(1). 11-20. https://doi.org/10.31172/jmg.v10i1.31.
Qian, J-H. (2019). Multi-scale Climate Processes and Rainfall Variability in Sumatra and Malay Peninsula associated with ENSO in boreal fall and winter. Int. J. of Clymatol. 40. 4171-4188. http://doi.org/10.1002/joc/6450.

Ruigar, H. and Gulian, S. (2015). Assessing the Correlation Between Climate Signals and Monthly Mean and Extreme Precipitation and Discharge of Golestan Darm Watershed. Eart Sci. Res. J. 19(1). 65-72. http:// dx.doi.org/10.15446/esrj.v19n1.40996.

Salhi, A., Martin-Vide, J., Benhamrouche, A., Benabdelouahab, S., Himi, M., Benabdelouahab, T., and Ponsati, A. C. (2019). Rainfall distribution and trends of the daily precipitation concentration index in northern Morocco: a need for an adaptive environmental policy. SN Applied Sciences. 1:277. https://doi.org/10.1007/s42452-019-0290-1.

Saunders, K., Stephenson, A. G., Taylor, P. G., and Karoly, D. (2017). The spatial distribution of rainfall extremes and the influence of El Nino Southern Oscillation. Journal Weather and Climate Extremes. 18. 17-28. http:// doi.org/10.1016/j.wace.2017.10.001.

Sekaranom, A. B., Nurjani, E., Harini, R., and Muttaqin, A. S. (2020). Simulation of Daily Rainfall Data using Articulated Weather Generator Model for Seasonal Prediction of ENSO-Affected Zones in Indonesia. Indonesian Journal of Geography. 52(2). 143-153. http:// dx.doi.org/10.22146/ijg.50862.

Sinambela, W., Dani, T., Rusnadi, I. E., dan Nugroho, J. T. (2008). Pengaruh Aktivitas Matahari pada Variasi Curah Hujan di Indonesia. Jurnal Sains Dirgantara. 5(2). 149-168.

Suhaila, J. and Jemain, A. A. (2012). Spatial Analysis of Daily Rainfall Intensity and Concentration Index in Peninsular Malaysia. Theor. Appl. Climatol. 108. 235-245. http:// doi.org/10.1007/s00704-011-0529-2.

Tukidi (2010). Karakter curah hujan di Indonesia. Jurnal Geografi. 7 (2). 136-145. Department of Geography Universitas Negeri Semarang. https://doi.org/10/15294/jg.v7i2.84.

Yang, X., Xie, X., Liu, D. L., Ji, F., and Wang, L. (2015). Spatial Interpolation of Daily Rainfall Data for Local Climate Impact Assessment over Greater Sydney Region. Advances in Meteorology. 2015. 12 pages. https:// doi.org/10.1155/2015/563629.

Yuggotomo, M.E. dan Ihwan, A. (2014). Pengaruh fenomena El Niño Southern Oscillation dan Dipole Mode terhadap curah hujan di Kabupaten Ketapang. POSITRON. IV(2). 35 - 39. http://dx.doi.org/10.26418/positron.v4i2.7563.

Zeinivand, H. (2015). Comparison of Interpolation Methods for Precipitation Fields Using the Physically Based and Spatially Distributed Model of River Runoff on the Example of the Gharesou Basin, Iran. Russian Meteorology and Hydrology. 40(7). 480-488. https:// doi.org/10.3103/S1068373915070079. 